\title{
INSIDE WORK
}

\author{
Laying new pipe \\ for a watering trough. \\ Digging up the packed manure, \\ the locked smell leaking \\ from beneath each shovelful. \\ The posts speckled with flies, \\ gnawed at the bottom by generations of hogs. \\ The jackhammer breaks the concrete in a jagged line \\ across the barn floor. In the grimy dirt \\ under the foundation- \\ half of a horseshoe buried in 1910. \\ Sweating, leaning on the shovel, staring \\ into the barnyard at the pigs standing in the rain.
}

\section{THE HUNTER \\ for Bill Gilson}

\begin{abstract}
All afternoon we passed deer coming down from the mountains in the backs of pickup trucks and on the fenders of cars. There was a buck on the car next to us at the toll booth, his head hung over the side so one eye followed the road, the other filled with snowflakes while we idled. His tongue was frozen to the fender. There's the hunter! I can tell. Slumped in the back seat. His face like a moon in the blurred window, watching the gray miles darken toward home; trying to conjure that brightness again, eyes closed in the headlights, he tries to remember the light the deer walked in.
\end{abstract}

